\title{
DIE OORSPRONG VAN DIE BOSE IN ANTIEKE GESKRIFTE
}

\author{
Elmarie Louw-Kritzinger \\ Antieke Studie \\ Universiteit Stellenbosch
}

\begin{abstract}
Current publications and polemics attest to the on-going efforts to explain Evil and death to post-modern man 'acceptably'/scientifically? - the theodicy that has already been grappled with in the ancient writings. The search for the origin of Evil is one of the numerous facets in this virtually impossible undertaking. In ancient times, a deeper meaning was attached to name-giving. The obvious starting point is in the names given to the Evil in the Ancient Writings. Various names are used in turn for the Evil One. Each name reflects an aspect of the Entity. However, it is interesting to note that the names do link with one another. A further line of tradition that is closely connected to the Two Spirits in the Zoroastrianism, is the choice that every person must make between Good and Evil. Thus the Two Spirits are placed within man and by his choice expanded into two cosmic powers. This research on the ancient writings attempts to contribute to the ongoing unravelling and wording of this burning question.
\end{abstract}

Key Words: Theodicy, Proper names for the Evil, the choice between Good and Evil, Moderate Dualism, Zoroastrianism, Qumran Literature, New Testament (Revelation)

\section{Inleidend}

Met die navorsing van geskrifte ${ }^{1}$ uit die antieke literatuur vir 'n DPhil-tesis ${ }^{2}$ het 'n onderliggende teologiese vraagstuk sterk op die voorgrond getree: die tergende probleem van hoe 'n Almagtige, Alwetende, Wyse en Goeie God die Bose met al sy afgryse in die wêreld kan 'toelaat' om hoogty te vier.

Gedurende die tydsduur van bovermelde navorsing het die aanval op die Twin Towers in Amerika plaasgevind, asook die voortslepende oorlog in Iran, Irak, Afghanistan en verdrukking en hongersnood in sommige Afrikastate soos Zimbabwe en Soedan. Natuurrampe, soos die oorstromings deur die tsunami in die Ooste het skokgolwe deur die hele mensdom op die aarde gestuur. Meer onlangs het die verwoestende brande in Australië die broosheid van die mens onderskryf. Die volgehoue aktualiteit van dié knelvraag deur die eeue heen en oor die hele omvang van die wêreld, word deur die enkele voorbeelde bevestig.

Op 'kleiner skaal' het berigte in die koerante van die RSA oor 'n moord, wat deur 'n skoolseun met 'n swaard op 'n maat gepleeg is en wat aan Satanisme gewyt is, weer die

Die Gathas van Zarathushtra en die Bahman Yasht (Zoroastrisme); die Oorlogsrol van die QL (Qumran Literatuur) en Openbaring in die Nuwe Testament (NT) is onder die loep geneem. Die onderwerp onder bespreking word hoofsaaklik aan die hand van die geskrifte bespreek met die Geskrifte van die Hebreeuse Bybel (HB) as agtergrond vir die Judaïsme en die NT.

2 Louw-Kritzinger, EM 2008. Die Eskatologiese/Apokaliptiese Oorlog tussen Goed en Kwaad in die Zoroastrisme, die Judaïsme (Qumran) en 'n vroeg-Christelike Geskrif (Die Apokalips). Universiteit Stellenbosch. 
vraag na die Bose en die invloed en oorsprong daarvan laat opvlam. 'n Ondersoek deur 'n takspan na die bestaan en oorsprong van Satan is deur die NGK in 2007 gelas. ${ }^{3}$ Die boek, The Shack ${ }^{4}$ waarin 'n man met die sin van 'n wrede moord op sy dogtertjie worstel, het oornag 'n blitsverkoper geword. Bestaan die Duiwel regtig? ? $^{5}$ het pas op die rakke van boekwinkels verskyn.

Dit getuig van die toenemende bevraagtekening deur die man-in-die-straat van teologiese leerstellings wat vroeër as aksiomas voorgehou en aanvaar is. Die onlangse polemiek in die By van Die Burger word saamgevat deur die skuilnaam van een van die deelnemers: 'Soek Antwoorde'. ${ }^{6}$ Teoloë word al hoe meer gedaag om antwoorde in 'n verstaanbare taal aan Jan Alleman te verskaf. Die mens in die post-moderne konteks wil die probleem wetenskaplik benader en beredeneer - soos 'Soek Antwoorde' dit stel:

Dit is opvallend dat al hoe meer mense openlik begin om vrae te vra oor die Bybel. Selfs gewaagde vrae wat diep sny. My geslag is grootgemaak dat dit sonde is om die Bybel te bevraagteken ... Die mens is ' $n$ intellektuele wese en dit was onvermydelik dat hy die een of ander tyd gaan begin vrae vra ... Wie het in elk geval die Duiwel gemaak wat die ander rede is vir die mens se val?

Die oopstelling van meer 'akademiese' inligting ${ }^{7}$ word bevorder deur die teologiese knelvrae aan die leek, sowel as aan die navorser, meer toeganklik voor te stel. Dit word veral in twee boeke van Boyd ${ }^{8}$ geïllustreer. Boyd (1997:33-35) draai nie doekies om nie en teken die Bose as 'n werklike konkrete realiteit deur die skrynende verslag van 'n ooggetuie van die gebeure om Zosia uit die Vervolging van die Jode, as 'n voorbeeld van al die terreur en afgryse wat deur die eeue heen plaasgevind het, voor te hou:

If God is all-loving and perfectly good, he must want to protect Zosia. And if God exercises total control over the world, he must be able to protect Zosia. Yet Zosia suffers an unspeakable ordeal, then is murdered. This makes no sense and constitutes, in its starkest form, the intellectual problem of evil (Boyd 1997:35).

Hy (Boyd 1997:35-40) pak die teodisee ${ }^{9}$ vanuit 'n Geestelike Oorlogsvoering-wêreldbeskouing ${ }^{10}$ aan, contra die klassieke-filosofiese tradisie van die Christelike kerk wat deur die vroeëre kerkvaders, Augustinus en Aquinas voorgehou is en deur Calvyn en die Hervormers voortgedra is. Hy skroom nie om vrae, wat vroeër as godslasterlik beskou is, te stel nie:

De Villiers, J 2007. NGK to check if Satan exists. Die Beeld: Junie 4.

Young, WP 2007. The Shack. Windblown Media: Newbury Park.

Joubert, S, Van der Walt, J \& Du Plessis, G 2009. Bestaan die Duiwel regtig? CUM: Vereeniging.

Hutspot. 2008 By, Die Burger: 2, Desember 20.

In Afrikaans is byvoorbeeld die meer onbekende Apokriewe boeke aan die leek voorgestel:

Mijnhart, F 1996. Apokriewe van die Ou Testament. JL van Schaik: Pretoria.

Van der Watt, J \& Tolmie, F 2005. Apokriewe Ou en Nuwe Testament. Christelike

Uitgewersmaatskappy:Vereeniging.

8 Boyd, GA 1997. God at War: the Bible and Spiritual Conflict. InterVarsity Press: Illinois; Boyd, GA 2001. Satan and the problem of Evil: Constructing a Trinitarian Warfare Theodicy. InterVarsity Press: Illinois.

9 Du Rand (2008:124) definieer teodisee as "die poging om die probleem van die bose en die dood te verduidelik".

10 Boyd (1997:24) spel dit duidelik uit dat hy as 'n toegewyde evangeliese Christen, met 'n 'kanonieke benadering' tot die Geskrifte, skryf en nie probeer om 'n neutrale 'beskrywende' perspektief weer te gee nie. Hy staan 'n objektiewe, skrywergesentreerde hermeneutiese benadering voor, wat in 'n sterk, bindende beskouing deur goddelike inspirasie gewortel is. 
Christian orthodoxy, of course, has always taught that God is omnipotent, and for good reason. Scripture is unequivocal on this point. But the question that needs to be asked is this: Does this omnipotence necessarily entail that God is all-controlling, as the classicalphilosophical tradition after Augustine has been inclined to assume? Does affirming that God is omnipotent commit one to the view that a good divine purpose lies behind all particular events, as the above hymn suggests? If it does, then it seems that we must consider both the rage of the unbeliever and the shallow, trite piety of the believer to be essentially correct. Zosia's torment, then, is indeed from her heavenly father's loving hand. In what follows, however, I propose an alternative understanding, one that I believe characterizes both the Bible and the early pre-Augustinian church, and one that avoids the unacceptable consequences of the Augustine model (Boyd 1997:41). ${ }^{11}$

Die vroeë patriargale en monargale geskiedenis van die volk van God kan as 'n siklus van afdwaling van die Wet van God; vermaning deur die profete; straf deur God; die berou en terugkeer van die volk en God se vergifnis, geteken word. Die oorrompeling en wegvoering van Israel deur die magte van die Assiriërs en die Babiloniërs het hulle egter as volk afgetakel en hul gestroop van hul land. Hulle reaksie in die verpletterende omstandighede was paradoksaal: "As Judah's situation on the mundane level deteriorated in history, the cosmic status of its deity soared in its literature" (Smith 2001:165). "The concept of a single God whom all nations would eventually worship evolved among a conquered and exiled people no longer assured of their divinely protected status" (Shapero 1997:2; vgl. ook Mach 1999:25). Horbury (1998:37) is van mening dat die Bybelse literatuur van die Persiese tydperk 'n intense konsentrasie op God as koning en die koninkryk van God reflekteer, veral in die twee Liedere van Moses waar die Here as 'n oorlogskryger wat wraak teen Sy vyande neem, uitgebeeld word (Eks. 15:1-18; Deut. 32.36-43).

Die boek Jesaja benadruk dit deur die woorde van God in die tyd van Kores: ${ }^{12}$

Ek is die Here, en daar is geen ander nie; wat die lig formeer en die duisternis skep, die heil bewerk en die onheil- רָ - skep: Ek, die Here, is dit wat al hierdie dinge doen (Jes. $45: 6-7) .^{13}$

Daarteenoor het ' $\mathrm{n}$ ander perspektief begin posvat. Die ballingskap na Babilonië (587 v.C.) moes die tergende vraag - die steeds aktuele teologiese dilemma- van hoe so 'n almagtige God sy kinders aan soveel ontbering ${ }^{14}$ kon blootstel, laat opvlam het. ${ }^{15}$ God is tog goed en

11 Hierdie teodisee van Boyd voorveronderstel die bestaan van 'n tussen-in wêreld van geestelike wesens, wat oor vrye keuse beskik, asook 'n aanname dat boosheid- Satan en sy magte- op aarde te wagte moet wees. Dit hou die realiteit van radikale gebeurlikheid en werklike risiko in en kan die aarde in 'n ware oorlogsveld omskep (Boyd 1997:58).

12 Die meerderheid navorsers aanvaar tans dat 'n latere skrywer vir hoofstukke 40-55 en nog latere skrywer(s) vir 56-66 van Jesaja verantwoordelik was en dat die hoofstukke tussen 540-200 v.C. daaraan bygevoeg is (Clifford 1992:491).

13 Alle aanhalings in Afrikaans is uit die 1953 hersiene vertaling van Die Bybel geneem.

14 Sommige navorsers skaal die ervaring van die ballingskap vir die Israelitiese volk af en beweer dat die gevolge in navorsing oordryf word, terwyl sommige, soos Smith-Christopher (1997:7-36) opnuut 'n raming van die fisiese, sosiale en psigologiese impak wat die rampe van 597 en 586 v.C. op Antieke Israel gehad het, maak en die 'enormiteit' van die trauma benadruk.

15 Dis soos 'n eggo van die verhaal van Job (sommiges dateer die boek in die Persiese tydperk). Job is (as 'n individu - 'n 'regverdige') ook met die toestemming van God van al sy besittings gestroop en daar word deur hom en sy vriende met dié 'waarom'-vraag geworstel. Oplossing word nie deur 'n medegodheid vir die kwade gevind nie. Die aanklaer, die Satan, kom net in die eerste twee hoofstukke voor. In die verdere debat van Job met sy vriende word sondigheid vanaf die geboorte van die mens aan die mens self toegedig. 
Sy Skepping is goed- waar pas die Bose dan in Sy Skeppingsplan in? Hoe word die Bose met God vereenselwig?

\section{Benaming van die Bose}

'n Belangrike soekenjin in die nasporing van die oorsprong van die Bose in die antieke geskrifte is m.i. in die betekenis van aanvanklike soortname (wat na eiename ontwikkel het), wat daaraan toegeken is, geleë. Dis algemeen bekend dat gelaaide betekenis in die benaming van belangrike entiteite in die Antieke tydperk en latere geskrifte opgesluit was.

In die geskrifte van die HB word 'belial' 27 keer met meesal die betekenis van 'n euwel of boosheid, veral om die handeling van 'n persoon of groepe te beskryf, gebruik. ${ }^{16}$ In die

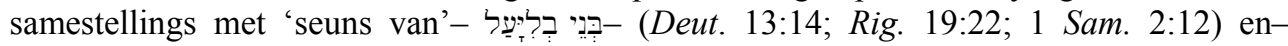

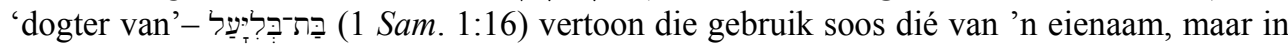
die konteks word dit beter as 'deugniet(e)' vertaal. Dit word ook in die HB saam met 'n

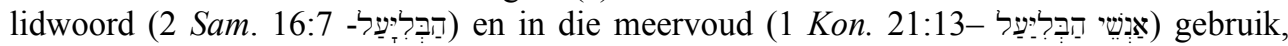
wat nie gewoonlik grammatikaal met die gebruik van 'n eienaam strook nie (Sperling 1999:169).

Die boosheid hang saam met pogings om mense te verlei tot afgodery (Deut. 13:13) of God nie te erken nie (1 Sam. 2:12); gruweldade (soos verkragting) teen die sosiale orde te pleeg (Rig. 19:22); oormatige gebruik van sterk drank (1 Sam. 1:16); minagting van die wet deur valse getuienis (1 Kon. 21:10; Spr. 18:28) en ondermyning van die gesag van die koning wat deur God aangewys is (1 Sam. 10:27; 2 Sam. 20:1). Hierdie voorbeelde van die boosheid hang saam met oortredinge - doelbewuste verkeerde gedrag - van die mense wat as sonde beskou is en kan as morele boosheid in die religie, kultuur, reg en staat beskryf word.

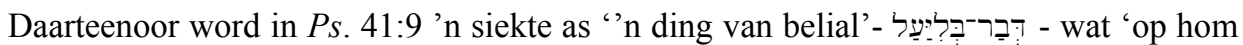
uitgestort' is, beskryf. Dit druk meer 'n fisiese boosheid/lyding uit wat nie deur die mens se handeling veroorsaak is nie, maar wel ook as 'n resultaat- straf op ongehoorsaamheiddaarvan verstaan kan word.

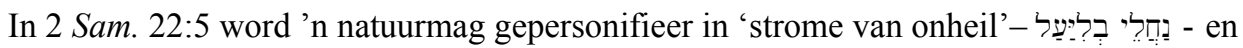

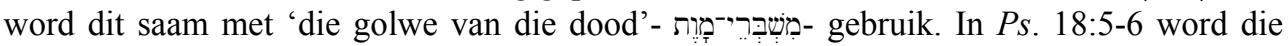

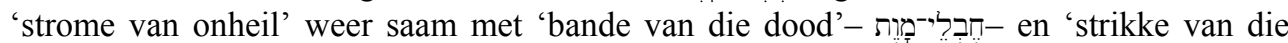

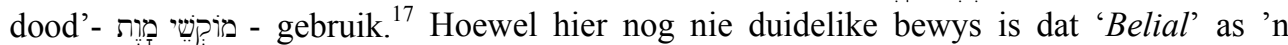
persoon gebruik word nie, sluit die bande en strikke opmerklik aan by die latere gebruik van die drie nette van Belial (Damaskusdokument 4.15-18)- מִצוּדָה. Die nette word beskryf as hoerery, rykdom/arrogansie en verontreiniging van die tempel ${ }^{18}$ wat ook in die bovermelde morele boosheid van Israel opgesluit is.

16 Etimologies is daar nog nie konsensus oor die woord se oorsprong nie, maar die ontleding dat die woord uit die negatief plus die betekenis 'om van waarde te wees' m.a.w. waardeloos (maar meer in die pejoratiewe sin van nikswerd te wees) word, as die mees aanvaarbare verklaring tot op hede beskou (Sperling 1999:171).

17 Volgens Collins (1998:101) verkies hy hier (saam met die gebruik van die dood wat dui op 'n assosiasie van Belial met die onderwêreld) die etimologiese verklaring met die betekenis van (die plek waarvandaan) 'n mens nie opgaan nie; of om te sluk - 'n werkwoord wat dikwels in die Kanaänitiese tradisie met Mot, die Dood verbind word. Hy verwys ook na Jes.25:7-8 waar gesê word dat God die Dood vir altyd sal insluk.

18 Oortredings (wetend of onwetend) teen die uitvoerige kultusstelsel met al die rituele en sakrale rites veral t.o.v. die reinheidswette het ' $n$ vername rol in die Israelse religie gespeel. Dit word meestal met die wortels van die terme afj, [ $\mathrm{wp}$ en $\div$ wa weergegee. 
In die Tussentestamentêre tydperk word 'Belial' wel - soos in $1 Q M$ (Oorlogsrol) - as eienaam in sommige van die ander Qumran-literatuur en in die pseudepigrafiese literatuur gebruik en dit in die sterk rol as leier van die Bose. Dit word bevestig deur die frekwensielys in die konkordans vir eiename in die Qumranliteratuur (Abegg 2002:232) ברליטֵַל die vyfde meeste - 91 keer - gebruik word.

In die Gemeenskapsrol (1QS) wat as die 'hart' van die sekte deur Dupont-Sommer (1968:68) beskryf word, word 'Belial' ook as die aanvoerder van die Seuns van die Duisternis gebruik - 1.18,24; 2.5,19; 10.21; so ook in die Damaskusdokument (CD 5.18-19; $8.2 ; 12.2)$ en in die Dankgesange (1QH 10:28-36). In laasvermelde word weer 'strome van onheil/Belial', maar hier saam met vuur gebruik, voorafgegaan deur '... die gramskap van Belial'.

Belial se raadgewing is gemik om te veroordeel en te vernietig (1QM 13.11). Dit sluit aan by bovermelde nette van Belial.

Belial is nie slegs die aanvoerder van die Seuns van die Duisternis nie, maar hulle dade word in die duisternis gepleeg (1QM 15.9) en hul riglyne vir die lewe is in duisternis (1QM 13.12). Dit sluit aan by die enigste verwysing na Belial in die NT (2 Kor. 6:14-15):

Moenie in dieselfde juk trek saam met die ongelowiges nie, want watter deelgenootskap het die geregtigheid met die ongeregtigheid, en watter gemeenskap het lig met die duisternis? En watter ooreenstemming het Christus met Bélial, of watter aandeel het die gelowige met die ongelowige?

Hulle is die 'lot van die duister' (IQM 1.11).

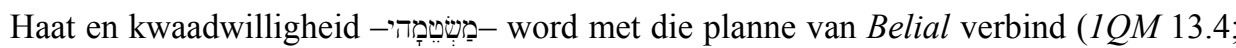
14.9; $C D$ 16.5; $1 Q S$ 3.23-24) en hy word die 'engel van vyandigheid' -

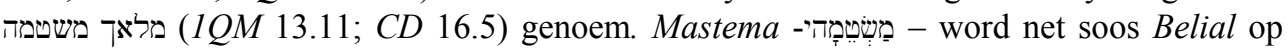
die twee plekke waar dit in die HB voorkom (Hos 9:7,8) as 'n naamwoord wat vyandskap

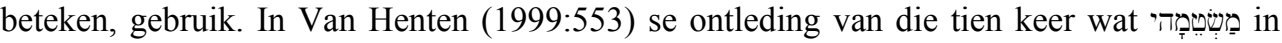
die Qumranliteratuur gebruik word, vind hy geen duidelike gebruik as eienaam, maar in Jub. 11.5 word Mastema die Prins - van die bose geeste genoem. (In 1QM 17.5-6 word Belial ook as die Prins - ש- van die bose ryk beskryf.) Van Henten (1999:553) vergelyk dit met 'n 'semantiese evolusie' van die woord 'Abaddôn, ${ }^{19}$ wat eers as naamwoord met 'n sekere konsep aan 'n engel verbind is, omdat die konsep die rol van die engel beskryf en later in die eienaam van die engel ontwikkel het. Dit kan ook op boosheid $<$ Belial toegepas word. $^{20}$

Mastema skakel weer aan Satan deurdat die werkwoordwortel van Mastema שָָָׁ met die betekenis van 'n wrok teenoor iemand koester of vyandiggesind teenoor iemand te wees, naasaan die wortel van Satan lê: שָָׁ - om 'n teenstander van iemand te wees of soos een op te tree; 'n aanklaer te wees of om iemand te laster. In Jub. 10:12 word Satan as 'n wisselvorm van Mastema gebruik.

19 אבֵּיון word van die werkwoord wat 'vernietig' beteken, afgelei en word met die onderwêreld en dood verbind. In Job 28:22 en Spr. 27:20 word dit gepersonifieer. In $O p$. 9:11 word dit as 'die engel van die bodemlose put/afgrond' omskryf en ook die Griekse weergawe daarvoor Apóllion (vernietiger) gegee.

20 Belial word ook met die dood en die onderwêreld geassosieer en skakel in die opsig met Abaddon. In 4Q286 word Abaddon wisselend met Belial en die Engel van die Put/Kuil gebruik. 
Van die nege kontekste waarin שָׁ in die HB gebruik word, verwys vyf daarvan na mense, meestal in die sin van 'n vyand van die mens en vier na hemelse wesens. ${ }^{21}$ Van die laasvermelde vier is daar net een waarvan שָׁ moontlik as 'n eienaam gebruik word. In Num. 22:22-35 word dit as 'n boodskapper van JHWHgebruik; in Job 1 \& 2 en Sag. 3:1-2

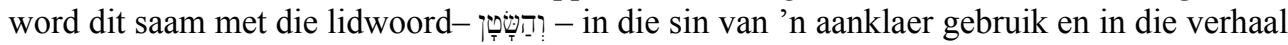
van Dawid se sensusopname in 1 Kron. 21:1-22:1 word dit sonder die lidwoord as aanklaer gebruik (Day 1999:726-730). Laasvermelde voorbeeld is meer problematies, aangesien dieselfde verhaal in 2 Sam 24 vertel word, maar in plaas van 'Satan' word dit met 'die toorn van die Here' omskryf. Die verskil is al as die verpersoonliking van die kwade en die ontwikkeling van Satan as God se bose vyand in die HB vertolk, maar die bewyse is te karig om te oortuig, veral omdat hierdie voorbeelde uit die na-ballingskapperiode (na 538 v.C.) kom en volgens Day (1999:730) kan die 'nou-datering' 'ontwikkeling' uitsluit.

Uit bovermelde blyk dit duidelik hoe die begrippe vir die Bose belial>mastema $>$ satan (ook $>$ Abaddon) aan mekaar skakel en is dit te verstane dat daar later wisselwerking tussen die gebruik van die name vir die Bose plaasgevind het.

Vir 'n meer holistiese kykie in die HB moet na die ander name van 'bose geeste' in die HB verwys word, veral aangesien sommige hulle verskyning weer in latere tekste maak soos in Openbaring. In Lev. 16:8,10,26 word verwys na soms as 'n woestyndemoon beskou word; in Lev. 17:7; 2 Kron.11:15 en Jes.13:21; 34:14 word שִׁעִיר as 'n 'veldduiwel' of 'veldgod' vertaal; in Jes. 34:14 word melding gemaak van

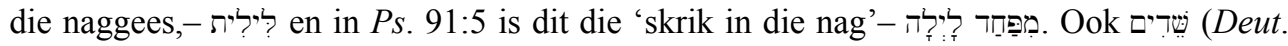
32:17 en Ps.106:37) word as 'duiwels' vertaal.

- ביהמטות Behemoth word nege keer in die HB meestal vir 'beeste/diere' gebruik, maar in Job 40:15 word hy as 'n spesifieke geweldige sterk dier beskryf wat ook in die water kan leef en word hy as een van die chaosmonsters, wat slegs deur $J H W H$ beheer kan word, vertolk.

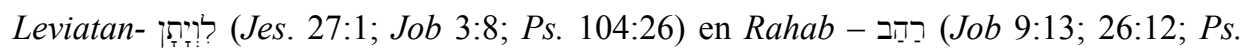
87:4; Jes. 30:7; 51:9), word albei - waarskynlik uit die mitologie van Ugarit - as 'n seeslang of seedraak met sewe koppe wat die oer-chaoswaters simboliseer, in die HB geteken. ${ }^{23}$ Hulle is in konflik teenoor $J H W H$ en word deur hom verslaan. Sommige verwysings dui op die skeppingstyd - Leviatan in Ps. 74:13-14 en Rahab in Ps. 89:11. Ps. 74:14 bevestig die 'koppe' van die seemonster. Skeppingsoorwinning oor Leviatan word 'n eskatologiese oorwinning in die eindtyd in Jes. 27:1:

In dié dag sal die Here met sy harde en groot en sterk swaard besoeking doen oor die Leviátan, die vinnige slang, en oor die Leviátan, die kronkelende slang; en Hy sal die draak doodmaak wat in die grootwater is.

21 שָָׁטון word as naamwoord 26 keer in die HB gebruik: sewe keer i.v.m.aardse mense en 19 keer verwys dit na hemelse wesens. Veertien (14) van die 19 keer word dit in Job 1 \& 2 as 'n hemelse satan/aanklaer gebruik (Hamilton 1992:985).

22 In een van die oudste boeke van Henog ( \pm 300 v.C.) - die Boek van die Wakers (1 Henog 1-36) - word in die mite oor die oorsprong van die boosheid, die Wakers deur twee engelfigure, Asael en Semih, in hul opstand in die hemel gelei. Aanvanklik was die opstandelinge nie as boos beskryf nie, maar na hul omgang met vroue op die aarde en die gevolglike reuse as nasate, wie se geeste die bose geeste op aarde word, kan die opstand as die oorsaak van die bestaan van bose geeste op die aarde en by implikasie ook van menslike sonde beskou word (Collins 1997:290).

23 Day $(1985: 3,19)$ gebruik die Chaoskampf-term in sy ontleding van Psalms 74, 89, 104, 65 en 93 om aan te toon dat die konflik tussen JHWH en die draak en die see met die skepping saamhang en volgens hom (1985:24) is daar reeds uit die tekste van Ugarit vasgestel dat die draak sewe koppe gehad het . 
Die apokaliptiese eienskap van Urzeit wird Endzeit is in die gedeelte al ter sprake (Day 1992:295) ${ }^{24}$ Die mities-poëtiese inslag van die literatuur hou die betekenis in dat die Skepper nog altyd opposisie van die kosmiese magte gehad het, dit nog voortdurend sal hê en dat Hy die mag gehad het, dit voortdurend sal hê om dit teen te staan en uiteindelik te verslaan (Boyd 2001:32). ${ }^{25}$

In Gen. 3 neem die bose die vorm van 'n slang aan, maar die slang word nie met Satan ${ }^{26}$ geïdentifiseer nie, hoewel sy kwaadwillige opstokery en sluwe verleiding van Adam en Eva teen God "terugskouend elemente toon wat eie aan die latere Satan is" (Vosloo 1992:389-390):

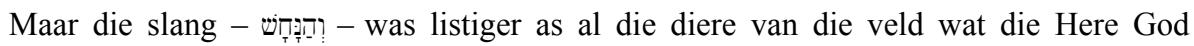
gemaak het (Gen. 3:1).

Die skrywer lys die slang saam met die ander diere wat deur God geskep is.

Volgens Hoffman (2004:18-19; 27) is daar nog geen werklike formulering/konsep van boosheid in die geskrifte van die HB nie en kan daar dus nie van 'simbole' vir die bose gepraat word nie of 'n bewussyn van die teologiese probleem van die bose nie. In die populêre geloof was daar heel waarskynlik 'n duideliker manifestering daarvan wat aanleiding tot die sadistiese en vermetele uitbeelding van die 'aanklaer' in Job gegee het.

In die HB gaan dit meer om die mens se doen van die bose dade/sonde. Dit word deur die basiese vorm van (ע) רע(ע) weergegee. In Konings word dit 63 keer gebruik en hou dit dikwels nie slegs die begrip van die bose wat mens doen nie, maar ook die gepaardgaande onheil/lyding in (Thiel 2004:3-4). Dit is dus duidelik dat boosheid en sonde hand aan hand gaan in die HB. Vyftig verskillende woorde word gebruik om aspekte van die sonde weer te gee. Die drie belangrikstes is און en פשע, wטאת waarvan die eerste ongeveer 595 keer in die

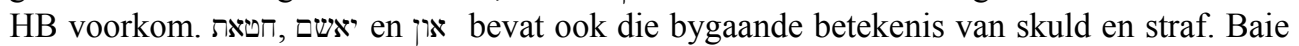
van die oortredinge weerspieël die verbreking van die Wet van God - die Tien Gebooie (Cover 1992:80).

Uit bostaande blyk dit dat die ervaring van die bose in die HB en simbole uit die vroeëre mitologie deur die skrywers van die literatuur van Qumran en die Apokriewe en Pseudepigrafieë weer in hul konteks gebruik en verder ontwikkel is. Die oorgang van die begrip 'boosheid/sonde' in ' $n$ bose persoon is ' $n$ aanvaarbare proses; veral in 'n poging om 'n oorsaak of 'n 'sondebok' vir die bose wandade te verkry om die skuld voor te gee. Die ontkieming daarvan is reeds in die bovermelde voorbeeld van 1 Kron. 21 te bespeur, asook deur die 'semantiese evolusie' van 'n oorheersende eienskap in 'n persoon. Wat wel opmerklik is, is die onverwagse sterk gebruik as 'n dualistiese opponerende leier van die bose magte teenoor God en sy leërmagte in die literatuur van die Tussentestamentêre Tydperk. Die Oorlogstoneel van $1 Q M$ is by uitstek die draer hiervan en die oorsaak dat navorsers na die nuwe konteks van Israel as bannelinge onder die Perse met 'n religie met 'n skerp dualistiese inslag, as matriks van dié ontwikkeling begin kyk het. Nie slegs kon die dualisme ' $\mathrm{n}$ rol gespeel het nie, maar die animisme in die wêreldvisie van die Zoroastrisme kon bygedra het tot die gemaklike oorgang van 'n begrip na 'n entiteit met 'n identiteit, domein en mag.

24 'n Samesmelting van gebeure in die oertyd en eskatologiese gebeure vind plaas (Batto 1992:172).

25 Die konflik met die kosmiese oermagte word soms met 'n oorlog teen die vyand van Israel verbind - Jes. 17:12-14 (Boyd 2001:32). Ook Day (1985:139) is van mening dat die draak en die see op die oorheersende wêreldmag van die tyd of vyandige nasies in die algemeen dui.

26 Die woord satan word nie een keer in Genesis in die HB gebruik nie. 
Daar is reeds verwys na die wisselwerking wat tussen die eiename van die Bose in die Tussentestamentêre Tydperk ontstaan het: Belial $>$ Mastema $>$ Satan $>$ Abaddon. Gedurende dié tydperk was die gebruik van Satan as eienaam in die Joodse geskrifte nog beperk en dit is eers in die geskrifte van die NT dat die gebruik meer algemeen geraak het. Die vroegste bewys van Satan as eienaam word tans bereken op ongeveer 168 v.C. in Jub. 23.29:

En al hul dae sal vervul wees en hul sal in vrede en vreugde lewe en daar sal geen Satan en geen bose (een) wat sal vernietig, wees nie.

Jub.10.12 is ook al aangehaal om aan te toon dat Mastema en Satan parallel gebruik word as die leier van die bose geeste.

In die literatuur van Qumran word Satan slegs drie keer (1QH 4.6; 45.3; $1 Q S b 1.8)$ gebruik en was Belial, soos reeds gesien, die mees algemene benoeming van die Bose (Hamilton 1992:985).

Satan word 35 keer in die NT gebruik: agt keer in Openbaring waarvan vyf in die briewe aan die gemeentes en drie in die daaropvolgende gedeeltes is:

In die brief aan die gemeente van Smirna ( $O p$. 2:9) word die sinagoge aan Satan verbind deur die 'lastering' van 'Jode' wat 'n 'sinagoge van die Satan' is

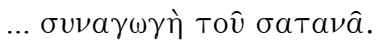

Dit word effens verskillend herhaal in die brief aan Filadelfía (Op. 3:9): "Kyk ek gee uit die sinagoge van die Satan van die wat sê dat hul Jode is en dit nie is nie, maar lieg..." Die gebruik van die woord 'sinagoge' dui dat die 'vyand' in die boesem van die gemeente voorkom. Vanaf die verwoesting van die Tempel in Jerusalem en die ballingskap in 587 v.C. het die vervanging van 'n heilige aanbiddingsplek 'n baie belangrike rol in die lewe van die ontwrigte Jode gespeel. Daar is nog geen definitiewe bewyse presies wanneer die sinagoges tot stand gekom het nie, maar gedurende die Tweede Tempeltydperk was hulle reeds alombekend en het ook as vergaderplek en skool gedien. Veral in die diaspora tussen die vreemde kulture moes dit die hartklop van die Joodse gemeenskap uitgemaak het. 'Lastering' sluit ten nouste by die oorspronklike betekenis van die woord Satan aan en net soos by die Oorlogsrol maak die mede-Jode deel van die vyand uit. Die Qumrangemeenskap het hulle heeltemal afgesonder van die Jode wat volgens hul mening die verkeerde onderrig van die 'Leraar van die Leuens' nagevolg het. Jesus en sy dissipels het nog die byeenkomste in die sinagoges bygewoon, maar volgens Openbaring het die

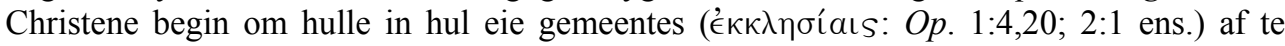
sonder. Hierdie tweespalt in die religieuse domein moes skrynerige gevolge midde-in die intieme binnekring van die Joodse gemeenskap gehad het. Uit die twee briewe kan voorts afgelei word dat sommige van die Jode selfs die Christene by die plaaslike bestuur aangekla het en dat dit wetlike implikasies tot gevolg gehad het (Op. 2:10).

In die brief aan die gemeente van Pergamus word Pergamus as die plek waar die 'troon van die Satan' is en 'waar die Satan woon' (Op. 2:13) uitgesonder. Pergamus was vanaf 300 v.C. tot 400 n.C. een van die belangrikste kulturele, religieuse, militêre en politieke sentra in Klein Asië. Die oudste deel van die stad was rondom die strategiese basis van die Acropolis, wat met 'n steil helling van ongeveer 1300 voet bo seespieël uitgetroon het, geleë. ${ }^{27}$ Veral aan die begin van die 2 de eeu n.C. het die herstel van die heiligdom van

27 Volgens Yabro Collins (1998:167-184) moet die 'troon van die Satan' nie slegs simbolies as 'n mag teen God vertolk word nie, maar kon dit ook deur 'n sigbare beeld - die Akropolis van Pergamus- verbind gewees het. So ook die kompleks van die tempels van Zeus en Atena en die Groot Altaar, aangesien die God Zeus sterk assosiasie met die keiser in hierdie tydgleuf van Johannes gehad het, terwyl die keiser weer met Satan deur Johannes verbind word. 
Asklepius bygedra tot die ontwikkeling van die vername intellektuele sentrum (veral op mediese gebied) onder die Romeine. Asklepius was uit die Griekse mitologie bekend as 'n god van genesing deur wonderwerke en is soms deur 'n slang voorgestel. Die kultus het saam met dié van Zeus, Atena en Dionysus, asook die kultus van die verering van die Romeinse Keisers nog verdere aanspraak op die inwoners van die stad gemaak. Laasvermelde was so geslaagd dat die gesogte benoeming as neōkoros drie keer aan Pergamus toegeken is. Ongetwyfeld moes die Christene wat nie aan die verering van die Keiser wou deelneem en die Romeinse Gode wou erken nie, skerp kritiek en verwerping verduur het en is waarskynlik as opstandelinge beskou. 'Troon' verwys duidelik na die koninklike heerskappy en mag. Die 'troon van die Satan' word in skerp teenstelling met die 'troon van God' - in 3:21 gebruik en in die daaropvolgende visioen van die troon van God in die vierde hoofstuk.

Die werkwoord wat vir 'woon' gebruik word- катоเк€îs - hou die betekenis van 'n meer permanente woonplek in. Dit benadruk die begrip dat Satan in Pergamus gesetel was.

In die brief an Thiatire word die kennis van Satan as die 'dieptes van die Satan' beskryf $(O p$. 2:24). In die 'dieptes' van die Satan kan sy onverstaanbaarheid en 'misterie' gelees word, maar dit sluit ook aan by die 'engel van die afgrond' wat in $O p$. 9:11 aan

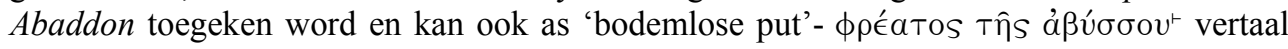
word.

Buiten die twee verse in $O p$. 12:9 en 20:2 waar die opstapeling van die name van Satan voorkom, word die eienaam, Satan weer in $O p$. 20:7 gebruik. Satan se laaste poging om deur oorlogsvoering te oorwin, na sy vrylating na 1000 jaar se gevangenisskap in die afgrond, word hier uitgebeeld.

'Satan' word dus in die inleidende briewe aan die sewe gemeentes in Openbaring as die vyand van die gemeentes van Christus geteken: nie slegs in hulle milieu van onaanvaarbare praktyke deur die ander gelowe en die keiserryk nie, maar veral deur mede-Jode en afdwalings van groepe in die binnekring van die gemeente. Die vyand, wat veral deur verleiding deur leuens en lastering/vervolging aanslag op die geloof van die jong gemeentes gemaak het.

Soos reeds gemeld, word daar twee keer in Openbaring vier benaminge vir die teenstander opgestapel - die draak; die slang; die duiwel en die Satan. Duiwel/Diabolos word in die geskrifte van die NT as leier van die Bose bygevoeg ${ }^{28}$ en word wisselend met Satan, soos in boveremlde tekste, gebruik sonder dat daar blykbaar enige noemenswaardige verskil in die betekenis is. $\Delta$ เáßo入os- lasteraar- is die vertaling van die LXX en die NT van Satan in die HB en die benaming word 32 keer in die NT gebruik - veral in die betekenis as die bonatuurlike Teenstander van God (Riley 1992:244).

Die verantwoordelikheid dat van die Christene in hegtenis geneem sou word, word in Op. 2:10 aan $\Delta$ เáßoגos toegeskryf. Dit is te wyte aan die 'lastering' van die 'Jode' - die 'sinagoge van die Satan' - in die vorige vers (2:9). $\Delta$ cáßoגos personifieer die vyand hier in die gestalte van die mede-Jode. In $O p$. 12:12 word 'groot woede' aan die duiwel toegeskryf.

In 20:10 word weer die eienskap van verleiding $-\pi \lambda a \nu \omega \hat{\omega} \nu$ aan die duiwel toegesê. Hierdie eienskap was waarskynlik die skakel waaraan die latere verbintenis van die slang in die Skeppingsverhaal in Genesis met die naam Satan te wyte is en speel 'n belangrike rol wat duidelik deur die herhaalde gebruik in verband met die 'vyand' in Openbaring na vore

28 Beëlsebul word net een keer in Matt. 12:24 as leier van die duiwels gebruik. 
kom. ${ }^{29}$ Die wisselwerking tussen die name vir die Bose kon ook bygedra het tot die assosiasie met die slang.

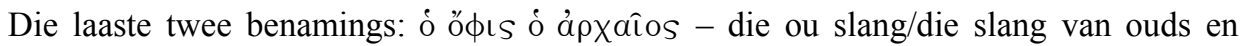

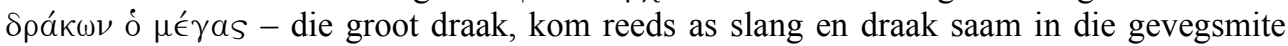
van die geskrifte van die HB voor: Jes. 27:1 (reeds angehaal). As sulks speel hul 'n belangrike rol in die simboliek van die 'oorlog' in Openbaring deurdat hulle die stryd op 'n kosmiese skaal plaas.

Die draak verskyn as 'n 'teken in die hemel' teenoor die swanger vrou in die visioen in $O p .12$. Die draak word beskryf as groot en vuurrooi met sewe koppe met krone en tien horings Dieselfde woord word gebruik om die 'vuurrooi' perd in $O p$. 6:4 te beskryf. Die perd word met 'n swaard en die dood verbind. In die konteks skakel die helderrooi met bloed. In die breër konteks van die Ou Nabye Ooste is ander mite-monsters ook in rooi geteken, bv. in Babilon het 'n rooi slang die god Marduk bewaak. Die sewe koppe met krone van die draak sinspeel op Satan se strewe om heerser op die aarde te wees, terwyl die tien horings die simbool van militêre mag uitmaak. Die beeld verwys waarskynlik terug na die vierde dier in die gesig van Daniël, wat ook tien horings gehad het (Dan. 7:1-8); die tien konings gedurende die tydperk van die vierde Heersersryk. Die Draak het oor nog 'n kragtige wapen beskik: met sy stert het hy 'n derde van die sterre 'meegesleep' en op die aarde neergegooi (12:4). Nadat hy die oorlog in die hemel teen Migael en sy engele verloor het, word die draak en sy engele ook op die aarde neergegooi (12:4). ${ }^{30}$ Afwisselend word die draak, die slang in 12:15-16 genoem. In die gedeelte het hy die vermoë om 'n rivier uit sy bek agter die vrou aan te gooi. ${ }^{31}$ Weereens word verleiding aan hom toegeskryf (Op. 12:9).

In teenstelling met die sterre in $O p .1: 20$ wat die 'engele van die gemeentes' voorstel, word in $O p .9: 1$ 'n gevalle 'ster uit die hemel' as die 'engel van die afgrond' voorgehou. Hierdie ster dra die naam van Alsem en die derde van die riviere en waterfonteine waarop dit geval het, het bitter geword en die mense het daarvan gesterf (8:10-11). In $O p$. 9:11 word bevestig dat die 'engel van die afgrond'-Abaddon/Apollion $-{ }^{32}$ die koning van die skrikwekkende leërmag van sprinkane is.

In 4Q286 word Abaddon wisselend met Belial en die Engel van die Put/Kuil gebruik. Die Hebreeuse woord word hoofsaaklik met die dood/vernietiging geassosieer, terwyl die Grieks ook die betekenis van 'vernietiger' oordra.

29 Die Wysheid van Salomo ( \pm 40 v.C.) wys op die 'jaloesie’ van die duiwel op Adam en Eva wat die oorsaak van die 'dood' was. In die geskrif is die duiwel as die slang in die tuin van Eden geïnterpreteer. In 1QH X111:26-27 word Belial ook met die gif van die slang geassosieer: “... Hulle smee boosheid in hul hart, [die manne van] Belial het 'n leuen-tong oopgemaak, soos die gif van adders wat aanhou vir tydperke soos hulle wat hulself in die stof neergooi betower hulle, slanggif, waarteen daar geen beswering is nie."

30 Hierdie visioen word vertolk as 'n variasie van die Griekse verhaal van die geboorte van Apollo, waarin die groot draak, Piton die godin Leto en haar kind wou doodmaak, maar deur Poseidon, die God van die see, gered word. Volgens Yabro Collins (1976:61-70) se vergelyking stem hierdie mite die meeste ooreen met dié een in Openbaring (kyk ook Reddish 2001:232). Koester (2001:118) verwys na die Romeinse Keisers soos Caesar Augustus en Nero wat die verhaal vir propaganda vir hulleself gebruik het deur hul in die rol van Apollo voor te stel.

31 Afgesien van die rol wat die slang in die skeppingsverhaal in Genesis gespeel het, was dit 'n bekende simbool in die Antieke wêreld - ook in die geskiedenis van Israel in die verhaal van die koperslang in die woestyn.

32 Volgens Grether (1992:301-302) verwys die Griekse ekwiwalent na die heidense god, Apollo. Die sprinkaan was 'n embleem van dié god wat sy slagoffers vergiftig het. Indirek kan dit ook die Romeinse keiser Domitianus, wat graag as die vleesgeworde Apollo beskou wou word, aandui. 
Die opstapeling van die vier name - die groot draak, die slang van ouds, Duiwel en Satan - tesame met die kosmiese uitbeelding van die oorlogvoerende draak en Abaddon dra by tot die eskalerende begrip van die totale som van die Boosheid.

Voorts het die ontleding van die geskrifte getoon dat dieselfde elemente/woorde/beelde vir die tekening van die Goeie en die Bose gebruik word. In Openbaring veral word 'n volgehoue nabootsing van die Bose in vergelyking met God en Christus aangetref. Hierdie fyn beplanning van verleiding deur verdraaiing van waarheid en goeie waardes kom van die Bose. Uit die perspektief van die protagonis word die nabootsing toegelaat om dit te ontmasker as 'n parodie - 'n valse, tydelike en waardelose namaaksel. In aansluiting wys Boyd (1997:276-277) daarop dat Satan in die NT nog as die 'god van hierdie wêreld'ò $\theta \in$ òs tô̂ aî̄vos (2 Kor. 4:4) beskou word en dat hy soos 'n "brullende leeu rondloop en soek wie hy kan verslind."(1 Pet. 5:8). In die boek van Johannes $(12: 31 ; 14: 30 ; 16: 11)$ word Satan ook as die "owerste/heerser van hierdie wêreld"- ó ă $\rho \chi \omega \nu$ Tov̂

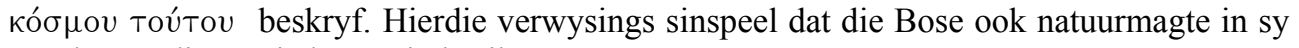
aanslag op die Goeie kan 'mis'bruik.

\section{Die keuse tussen die Goeie en die Bose}

Daar het gedurende die Tussen-Testamentiese Tydperk ook 'n klemverskuiwing ten opsigte van die rol wat die gelowige in die stryd teen die Bose speel, plaasgevind: die keuse wat die mens vrywillig tussen die Goeie en die Bose moet maak. Dit is veral in die QL benadruk. Die ontworteling deur die Ballingskap het heel waarskynlik die soeke na die oorsprong van die kwade en menslike boosheid $>$ sonde ontketen. So kan daar uit bovermelde voorbeeld van die latere boek, Kronieke (4de eeu v.C.), se weergawe van Dawid se sensusopname 'n poging om die Bose te verklaar, bespeur word in die klemverskuiwing van 'God se toorn' na '('n) satan' of 'Satan het opgetree/opgestaan' (וייְ⿱䒑䶹מד). Interessant dat slegs 'n paar woorde van Kronieke by die Qumrangrotte gevind is en dat dit in die Oorlogsrol $(13.10,11)$ pertinent deur die skrywer aan God toegeskryf word dat Belial verdorwe geraak het... "You have made Belial to corrupt, a hostile angel" (Duhaime 1995:123). 'n Ander vertaling (García Martínez 1994:108) stel dit nog sterker: "And Thou didst create Belial for the Pit..." Die Bose het 'gestalte' gekry in Belial, maar hy bly ondergeskik aan God. Belial word teenoor Migael, die hemelse kampvegter vir Israel, gestel. In $1 Q M$ word dit duidelik as getemperde dualisme geteken. Die komponent van die Bose - die vreesaanjaende leërmag - is 'n verskrikking, maar sal deur die Goeie vernietig word: $1 Q M$ 1.5-6 “..., and eternal annihilation/everlasting destruction for all the forces of Belial...without a remnant. There shall be no survivors". Aansluitend word daar in $1 Q M 1.11$ die motivering vir die stryd tussen die Seuns van die Lig en die Magte van die Duisternis gegee: dit is om die 'krag van God' te vertoon - גבורת אל. In hierdie rasionalisering van die oorlog kan 'n poging om die Goedheid van God teenoor die 'verskrikking' van die oorlog te regverdig, gelees word.

Sedert $1 Q S$ gepubliseer is, het navorsers al die moontlikheid van 'n ander onderliggende mite - die idioom van lig en duisternis van die Persiese dualisme - in die Manifes van die

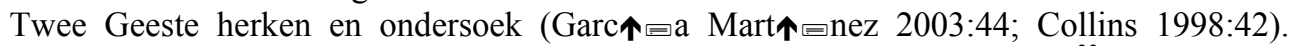
Aansluitend by $1 Q M$ bevestig die belangrike 'Manifes van die Twee Geeste' ${ }^{, 33}$ (kolom 3.134.26 van $1 Q S- \pm$ 100-75 v.C.) die opperheerskappy van God: ... מאל הדעות כול

33 Collins (1998:43) beskryf hierdie gedeelte as die 'kwintessens' van die teologie van die gemeenskap van die Dooie See. Dis as't ware die spil waarom hulle religie en hul lewenswyse gedraai het. 
- Van die God van kennis kom alles wat gebeur en wat sal gebeur ...” (1QS 3.15).

- In sy hande is die wette van alle dinge en hy ondersteun hulle in alles wat hul nodig het ... (1QS 3.16-17).

Dan vervolg die skrywer met die gedeelte wat 'n duidelike ooreenkoms met Yasna 30 toon:

Hy het die mens geskep om die wêreld te regeer en het twee geeste - רוחות - in die mens geplaas, dié van die waarheid en dié van die leuen, waarvolgens die mens moet lewe tot die oomblik van sy besoeking (IQS 3.18-19).

Die gedeelte word versterk deur kolom 4.23b-24a:

... Tot nou toe voer die geeste van die waarheid en die leuen 'n stryd in die hart van die mense en hul bewandel die pad van wysheid of slegtheid.

'n Etiese keuse by elke mens word hier geïmpliseer en daarvolgens word hulle lewenswandel bepaal en die mensdom in twee kosmiese dualistiese groepe, elkeen met 'n aanvoerder, verdeel:

In die hand van die Prins van die Ligte is die gesag oor die seuns van die geregtigheid; hulle wandel op die paaie van lig. En in die hand van die Engel van die Duisternis is totale gesag oor die seuns van bedrog; hulle wandel op die paaie van duisternis. Die Engel van die Duisternis laat die seuns van geregtigheid afdwaal en hulle sondes en hulle oortredinge, hulle tekortkominge en hulle opstandige dade vind onder sy gesag plaas in ooreenstemming met die geheimenisse van God, tot sy oomblik; ... "Nietemin die God van Israel en die Engel van sy Waarheid sal al die Seuns van die Lig bystaan" (1QS 3.20-25).

Hoewel 'n keuse aan die mens oorgelaat word om tussen die waarheid en die leuen te kies en hoewel die 'Engel van die Duisternis' hulle laat afdwaal, laat blyk die skrywer nog dat dit volgens die wil van God verloop - 'in ooreenstemming met die geheimenisse van God'.

Die skrywer wyk heeltemal af van die vroeëre rebellie-tema in 1 Henog. Hoewel daar 'n oorgang vanaf die woord 'Belial'/boosheid in die geskrifte van die latere HB na 'n verpersoonliking - die leier van die Bose - deur semantiese evolusie plaasgevind het, is ' $\mathrm{n}$ nuwe psigologies-etiese konsep bygevoeg. ${ }^{34}$ Die fokus val op elke mens se keuse. Vanaf die individu kring dit uit na 'n grootse kosmiese verdeling met 'n leier vir die Goed en die Kwaad. Hoewel dit nie radikale dualisme is nie, word die een pool herhaalde kere pertinent teenoor die ander een gestel.

Kortliks kan na Yasna 30:3-4 uit die Gathas van Zarathustra verwys word:

3. Waarlik daar is twee primêre Geeste, ('n) tweeling bekend om in konflik te wees. In gedagte en in woorde, in handeling is hul twee: die goeie/beter ${ }^{35}$ (een) en die slegte. En diegene wat goed handel, het die regte keuse tussen die twee gedoen, nie die boosdoeners nie.

4. Voorts het die twee geeste toe hulle die eerste keer by mekaar gekom het, lewe en nie-lewe geskep, en hoe aan die einde die Slegste Bestaan vir die bose sal wees, maar (die Huis van) die Beste Bedoeling vir die regverdige sal wees.

Volgens die vertaling word die twee Geeste as 'n tweeling omskryf, maar die een Gees word deur die vergelykende trap 'beter' bo die ander Gees gestel en strook dit nie met 'n radikale dualisme van twee oorspronklike ewewigtige entiteite nie. Die dilemma van navorsers is of die beeld meer letterlik as twee entiteite met 'n gesamentlike oorsprong (een

34 Shaked (1972:435) het na die gebruik van twjwr (geeste) in die QL in 'n psigologiese betekenis verwys.

35 Boyce (1984:35) en Humbach en Ichaporia (1994:31) vertaal dit met die vergelykende trap 'beter' wat deur die betekenis bevestig word. 
vader/moeder) of meer as 'n metafoor om die gelykheid van die twee wesens (hoewel tog effens ongebalanseerd deur die 'beter') vertolk moet word.

Bostaande Yasna word deur Yasna 45.2 bekragtig:

Ja, ek sal praat van die twee oer-geeste van bestaan, van wie die mees Heilige aan die Bose gesê het: 'Nie ons gedagtes nog ons leringe en voornemens, nog ons keuses, woorde, handelinge of ons innerlike of ons siele is in akkoord nie.'

Zarathushtra brei nie soseer uit oor die oorsprong van die twee geeste (mainy $\bar{u})$ nie, maar benadruk die belangrikheid van die keuse wat tussen die twee radikale verskillende beginsels van Goed en Kwaad deur elke mens gedoen moet word.

Yasna 30.2 lui inleidend:

Luister met jul ore na die beste dinge. Besin met 'n helder verstand - elke man vir homself - oor die twee keuses a avar na - vir'n beslissing ...

'n Keuse is onvermydelik want die 'tweeling' is in konflik met mekaar en is verskillend wat gedagte, woord en daad - allesomvattend: dit wat jy dink, dit wat jy praat en dit wat jy doen - betref.

Dié innerlike persoonlike handeling wat ' $n$ eie vrye keuse impliseer, plaas die dualisme op 'n psigologiese vlak, sodat dit as morele dualisme bestempel word. In hierdie sin sluit dit aan by die betekenis van mainyū as 'n 'mentality'. Volgens Bagli $(1996: 1,5)$ moet die Gathiese dualisme meer as etiese gedrag vertolk word en dat die 'oorsprong' van die twee 'aspekte' in die menslike verstand ('human mind') gesetel is, omdat daar 'n keuse tussen die twee gedoen moet word. Boosheid word deur die verkeerde keuses van die mens gegenereer. In hierdie konteks vertaal hy (Bagli 1996:2-3) die moeilike begrip van 'nielewe'- ajyäitīmcā as 'n waardelose lewenswyse' of 'n lewe wat nie werd is om te lewe nie'.

Dit is 'n baie aanvaarbare vertolking, maar slegs op 'n eerste vlak. In die metafoor word die begrip tog ook gepersonifieer deur die toeskrywing van gedagtes, woorde en handeling ens. aan 'n 'tweeling'. As entiteite word die Goeie Gees in die Gathas as Spenta Mainyu benoem en in 'n mindere mate die Bose Gees as Aka Mainyu in 32.5. Deur die personifikasie van die kwaliteite waartussen 'n keuse gedoen moet word, word die stryd op 'n kosmiese vlak geplaas; aansluitend by die betekenisnuanse as 'spirit/gees' vir mainy $\bar{u}$. Hoewel die Bose Gees oor baie mag beskik, is dit tydelik van aard en word dit baie duidelik in die Gathas gestel dat Ahura Mazda die Alleen-Opperwese is:

Maar ek het alreeds besef dat u Heilig/oorvloedig is Wyse Meester toe ek gesien het dat

$\mathrm{U}$ die Eerste Een by die skepping van die wêreld was en dat $\mathrm{U}$ dade en woorde deur $\mathrm{U}$

wysheid volgens hul waarde beloon, sleg vir die slegte, goed vir die goeie tot die

draaipunt van die skepping (43.5).

Die keuse - van die wortel var 'om te kies' of 'uit te kies' - het 'n sekondêre betekenis van 'te verkies' of 'te hou van'. Die uitkenning van die woord word vergemaklik deurdat dit 30 keer in die Gathas voorkom (Jafarey 2000:1). Dit word dus ook as 'voorkeur' in verskeie Yasnas gebruik: 31.11; 45.1,2; 48.4; 49.3. Die betekenis-nuanse van voorkeur sluit aan by die persepsie dat dit uit eie wil volgens elkeen se waardebepaling gedoen word: "... waardeur 'n persoon met eie wilskrag sy voorkeure te kenne gee" (31.11) en daarvolgens praat hy uit 'sy hart en sy verstand' (31.12).

Die wysgeer Ben Sira ( \pm 200 v.C.), het ook met dié teologiese kwessie vanuit 'n wysheidsperspektief geworstel. Hy het hoofsaaklik sy gedagtes deur middel van die beeld van die pottebakker verwoord: "Soos klei in die hande van die Pottebakker om te vorm na 
sy wil, so is almal in die hand van hul Skepper.” In 15.14 mak hy gebruik van verbuigings van die werkwoord צֶֶר /יצֶר ("inclination'/neiging) wat aansluit by bovermelde beeld deurdat צֵּר , ook 'pottebakker' beteken. ${ }^{36}$ Ben Sira brei die beeld verder uit deur by te voeg dat God die mens 'in die mag van sy neigings stel'. Hy benadruk die vrye keuse van die mens, maar slaag nie daarin om dit met die beeld van die Pottebakker en die klei te vereenselwig nie - die Goddelike determinisme en die menslike vrye keuse word nie gesinkroniseer nie (kyk ook bespreking in Collins 1997:83; Cook 2007:85-86).

Die mens se vryheid van keuse word in die Damaskus Dokument verder uitgebou - ook deur die menslike neiging- צֶר.. . Hewel daar 'n gedeelte is wat baie met die Manifes van die Twee Geeste ooreenstem, word die Twee Geeste nie in hierdie geskrif vermeld nie. ${ }^{37}$

Die vrywillige keuse van die mens word nie uitgespel in Openbaring nie, maar word geïmpliseer in die beeld van die 'geopende deur'. Christus is die sleuteldraer, Hy het die deur oopgesluit (Op. 2:7). Die visioen van die hemel is deur 'n 'geopende deur' (4:1). In Sy vermaning aan die selfgenoegsame gemeentelede van Laodisea sê Christus egter:

Almal wat Ek liefhet, bestraf en tugtig Ek. Wees dan ywerig en bekeer jou. Kyk, Ek staan by die deur en Ek klop. As iemand my stem hoor en die deur oopmaak, sal Ek ingaan na hom toe en saam met Hom maaltyd hou, en hy met My (Op. 3:19-20). (My aksentuering deur vet letters.)

Volgens Boyd (1997:285-286) word die vryheid van keuse vir die kosmiese magte of vir die mens nie in die NT bespreek nie, wel dat wanneer hulle sondig/rebelleer, hul oor dieselfde kam geskeer sal word (2 Pet. 2:4-9). Die woord wat die funksie van keuse in die NT vervul, is in bostaande aanhaling benadruk, nl. 'bekeer'. Die keuse van die volgelinge van Jesus het 'n 'omswaai/verandering' van mening oor die bestaande Joodse leringe beteken en 'n definitiewe wilsbesluit behels. Metanoia word gebruik om uitdrukking aan die nuwe denkpatroon, wat tog ook op die geskrifte van die HB gebaseer was, te gee. Dit dra ook die betekenis van 'berou/inkeer'.

\section{Samevattend}

Die sleutel-betekenisse van die benoeming van die Bose in boveremlde geskrifte kan hoofsaaklik in drie hoofgroepe ingedeel word:

- Die beskrywing van die wandade/sonde van die mens - belial.

- Die boosheid word gepersonifieer en aan die Vyand-Mastema - toegeskryf, wanneer dit in krisisse alle 'regverdiging' oorskry. Sy wapens is hoofsaaklik laster, leuens en verleiding - Satan. Sy mikpunt is die dood en vernietiging - Abaddon.

- Natuurrampe/onheil word as straf op sonde vertolk. In die bostaande aanhaling uit Openbaring 3:19-20 word dit duidelik gestel dat Christus 'bestraf en tugtig', maar dit

36 Hierdie beeld van die noodsaaklike kunsvlyt is reeds in Jes. 45:9; 64:7 en Job 10:9 gebruik, maar meer in die sin om die verhouding tussen Skepper en skepsel weer te gee bv. Jes. 64:8:“...ons is die klei, en u is ons Formeerder, en ons is almal die werk van u hand".

37 In die fragment van die Testament van Amram (4QAmram), wat ook tussen die QL gevind is en ongeveer 200 v.C. gedateer word, word drie name aan elk van die dualistiese teenstanders toegeken. Net een naam kan op die fragment duidelik ontsyfer word - Melchiresha - 'koning van boosheid'. Die ander kan deur redelik aanvaarbare verwysing na die res van die Qumranrolle as drie pare teenoormekaar gestel word: Migael/Belial; Melchizedek/Melchiresha; Prins(engel van lig)/Prins/(engel van duisternis). Die fragment stel 'n nuwe perspektief bekend: die verhaal van die stryd tussen die goeie en die bose engele vir die besitting van 'n mens na die dood. Kobelski (1981:75) is van mening dat dit heel waarskynlik uit die hemelse hoftonele in die HB ontwikkel het. 
word met 'liefde' gekwalifiseer. Die Bose word as 'n skynbeeld van die Godheid geteken en dat hy ook die natuur en onheil in sy oorlogsvoering gebruik. In 2 Kor. 11:14 verander Satan hom selfs in '’n engel van die lig'.

Midde-in die dilemma word die mens voor die keuse, waardeur die leërmag van die Goeie of die Bose versterk word, gestel. Dit behels vryheid, maar ook verantwoordelikheid.

Wanneer die uitgangspunt dié van God wat oorlog teen die Bose voer, is en nie God wat die Bose kontroleer, is nie, word die intellektuele probleem van boosheid 'n praktiese probleem wat bekamp moet word - aldus Boyd (1997:291).

Die post-moderne 'intellektuele' mens ervaar dat die Bose nog steeds afbrekend, misleidend, verswelgend en vernietigend is en dat dit nog steeds in 'n groot mate aan die mens te wyte is, ten spyte van die beklemtoning van gelykheid en menseregte. Die Bose is 'n aksioma op aarde - daarsonder is dit 'n paradys. Die vraag bly of elke mens/kind binne sy eie konteks wel oor 'n keuse beskik? Boyd (1997:58,292-293) put meer sin daaruit om in sy oorlogsvoering-raamwerk al die Zosias as gesneuweldes in die oorlog teen die Bose te vertolk.

In Afrika-konteks: hierdie is maar die puntjies van die seekoei se ore.

\section{BIBLIOGRAFIE}

Abegg, MG Jr. 2002. Concordance of Proper Nouns in the Non-biblical Texts from Qumran, in Tov, E (red.), The Texts from the Judaean Desert, XXXIX: 229-284. Minneapolis: Fortress Press.

Bagli, EJ 1996. Twin Mainyus - The Gathic Doctrine. Beskikbaar: http://www.vohuman.org/Article/Twin\%20Mainyus.htm|-November 2005.

Batto, BF 1992. Slaying the Dragon. Mythmaking in the Biblical Tradition. Kentucky: Westminster/John Knox Press.

Boyce, M 1984b. Textual Sources for the Study of Zoroastrianism. New Jersey: Barnes \& Noble Books.

Boyd, GA 1997. God at War. The Bible and Spiritual Conflict. Illinois: InterVarsity Press.

Boyd, GA 2001. Satan and the Problem of Evil. Constructing a Trinitarian Warfare Theodicy. Illinois: Intervarsity Press.

Breytenbach, C \& Day, PL 1999. Satan, in Van der Toorn, Becking, B \& Van der Horst, PW (red.), Dictionary of Deities and Demons in the Bible. Leiden: Brill. 727-732.

Clifford, RJ 1992. Second Isaiah, in Freedman, DN (red.), The Anchor Bible Dictionary. New York: Doubleday, 3:490-501.

Collins, JJ 1984. The Sibylline Oracles, in Stone, M E (red.), Jewish Writings of the Second Temple Period. Philadelphia: Fortress Press. 357-381.

Collins, JJ 1997. Jewish Wisdom in the Hellenistic Age. Louisville: Westminister John Knox Press.

Collins, JJ 1998. Apocalyptism in the Dead Sea Scrolls. 2de uitg. New York: Routledge.

Cook, J 2007. The Origin of the Tradition of the צטר הרע and JSOT, 38: 80-91. 
Cover, RC 1992. Sin, Sinners. Old Testament, in Freedman, DN (red.), The Anchor Bible Dictionary. New York: Doubleday, 6: 31-46.

Davidson, MJ 1992. Angels at Qumran. A Comparative Study of 1 Enoch 1-36, 72-108 and Sectarian Writings from Qumran. Sheffield: Sheffield Academic Press.

Davies, PR 2000. Death, Resurrection, and Life after Death in the Qumran Scrolls, in Avery- Peck, AJ \& Neusner, J (red.), Judaism in Late Antiquity. Leiden: Brill. 189-214.

Day, J 1985. God's conflict with the dragon and the sea. Echoes of a Canaanite myth in the Old Testament. Cambridge: Cambridge University Press.

Day, J 1992. Dragon, in Freedman, D N (red.), The Anchor Bible Dictionary. New York:Doubleday, 2:228-231.

Duhaime, J 1995. War Scroll (1QM; 1Q33; 4Q491-496=4QM1-6;4Q497), in Charlesworth, J H (red.), The Dead Sea Scrolls Hebrew, Aramaic, and Greek texts with English Translations. Louisville: Westminister John Knox Press, 2:80-198.

Dupont-Sommer, A 1961. The Essene Writings from Qumran. Oxford: Basil Blackwell.

Du Rand, J 2008. Theodicy Provides New Perspectives on God According to 4 Ezra, in Ephemerides Theoligcae Lovanienses 84/1:123-124.

García Martínez, F 1994. The Dead Sea Scrolls Translated. Leiden: Brill.

García Martínez, F 2003. Iranian influences in Qumran? in McNamara, M (red.), Apocalyptic and Eschatological Heritage. The Middle East and Celtic Realms. Dublin: Four Courts Press. 37-49.

Grether, HJ 1992. Appolyon, in Freedman, D N (red.), The Anchor Bible Dictionary. New York: Doubleday, 1:301-302.

Hamilton, VP 1992. Satan, in Freedman, D N (red.), The Anchor Bible Dictionary. New York: Doubleday, 5:985-989.

Hoffman, Y 2004. Jeremia 50-51 and the Concept of Evil in the Hebrew Bible, in Reventlow GH \& Hoffman, Y (red.), The Problem of Evil and its Symbols in Jewish and Christian Tradition. London: T\&T Clark International, 14-28.

Horbury, W 1998. Jewish Messianism and the Cult of Christ. London: SCM Press Ltd.

Humbach, H \& Ichaporia, P 1994. The Heritage of Zarathushtra. A New Translation of his Gāthās. Heidelberg: Universitätsverlag.

Jafarey, AA 2000. Freedom of Choice. Meaning and Message of Yasna 30:2. Beskikbaar: http://www.zoroastrian.org./articles/.htm| Julie 2006.

Jafarey, AA 2005. "Spenta Mainyu” and Good and Evil in the Gathas. Beskikbaar: http://www.zoroastrian.org/articles| Julie 2006.

Kobelski, PJ 1981. Melchizedek and Melchireša ${ }^{c}$. Washington: The Catholic Biblical Association of America.

Koester, CR 2001. Revelation and the End of All Things. Michigan: William B Eerdmans Publishing Company.

Mach, M 1999. Concepts of Jewish Monotheism during the Hellenistic Period, in Newman, CC, Davila, JR \& Lewis, GS (red.), The Jewish Roots of Christological Monotheism. Leiden: Brill. 21-42. 
Mijnhardt, F 1996. Apokriewe van die Ou Testament. Pretoria: JL van Schaik.

Nickelsburg, GWE 1981. Jewish Literature Between the Bible and the Mishnah. Philadelphia: Fortress Press.

Nicklesburg, GWE 1991. The Apocalyptic Construction of Reality in 1 Enoch, in Collins, JJ \& Charlesworth, JH (red.), Mysteries and Revelations. Apocalyptic Studies since the Uppsala Colloquium. Sheffield: JSOT Press. 51-64.

Nickelsburg, GWE 1992. Son of Man, in Freedman, D N (red.), The Anchor Bible Dictionary. New York: Doubleday, 6:137-150.

Nicklesburg, GWE 2001. 1 Enoch. A Commentary on the Book of 1 Enoch, Chapters 1-36, 81-108. Minneapolis: Fortress Press.

Reddish, MG 2001. Revelation. Georgia: Smyth\&Helwys Publishing, Inc.

Riley, GJ 1992. Devil, in Freedman, DN (red.), The Anchor Bible Dictionary. New York: Doubleday, 1:244-249.

Shaked, S 1972. Qumran and Iran: Further Considerations. Israel Oriental Studies, 2:433-446.

Shapero, HMG 1997. Zoroastrianism, Judaism and Christianity. Beskikbaar: http://www.pyracantha.com/zjc.htm |

Smith, MS 2001. The Origins of Biblical Monotheism. Oxford: Oxford University Press.

Smith-Christopher, D 1997. Reassessing the Historical and Sosiological Impact of the Babylonian Exile (597/587-539 v.C.), in Scott, JM (red.), Exile. Old Testament, Jewish, and Christian Conceptions. Leiden: Brill. 7-36.

Sperling, SD 1999. Belial, in Van der Toorn, K, Becking, B \& Van der Horst, P W (red.), Dictionary of Deities and Demons in the Bible. DDD. Leiden: Brill, Thiel, W 2004. 'Evil' in the Books of Kings, in Reventlow, H G \& Hoffman, Y (red.), The Problem of Evil and its Symbols in Jewish and Christian Tradition. London: T\&T Clark International, 2-13.

Van der Watt, J \& Tolmie, F 2005. Apokriewe. Ou en Nuwe Testament. Vereeniging: Christelike Uitgewersmaatskappy.

Van Henten, JW 1999. Mastemah, in Van der Toorn, Becking, B \& Van der Horst, PW (red.), Dictionary of Deities and Demons in the Bible. Leiden: Brill. 553-554.

Vosloo, W 1992. Die Ou Testament oor Demone en die Satan. In die Skriflig, 26/3:387-396.

Yarbro Collins, A 1976. The Combat Myth in the Book of Revelation. Missoula MO: Scholars Press.

Yarbro Collins, A 1998. Pergamon in Early Christian Literature, in Koester, H (red.), Pergamon Citadel of the Gods. Pennsylvania: Trinity Press International 167-184. 